\title{
Mycoplasmas and bacteria in synovial fluid from patients with arthritis
}

\author{
P.-A. MÅRDH, F. J. NILSSON, AND A. BJELLE \\ From the Departments of Medical Microbiology and Rheumatology, University of Lund, Lund, Sweden
}

Recent years have witnessed a revival of interest in a possibly infectious aetiology of various forms of chronic arthritis in man. The results of investigations of the occurrence of micro-organisms in joints of such patients have been difficult to interpret. Lately, interest has been focused particularly on mycoplasmas (c.f. Table I; Williams, Brostoff, and Roitt, 1970; Smith and Ward, 1971) and 'diphtheroid' rods (Duthie, Stewart, Alexander, and Dayhoff, 1967; Bartholomew and Nelson, 1972a).

In the present study synovial fluid collected from knee joints of consecutive patients with rheumatoid arthritis (RA) or non-rheumatoid acute gonitis were cultured for mycoplasmas, bacteria, and L-phase variants of bacteria. Cultures for mycoplasmas were also made from the urogenital tract of the patients with RA. Mycoplasma fermentans was found in a few of the synovial fluids. Such strains were examined for their susceptibility to antibiotics and antirheumatic agents. Further, sera of the patients with RA and from healthy controls were studied for in-

Accepted for publication December 14, 1972. direct haemagglutinating and metabolism-inhibiting antibodies to $M$. fermentans. In view of the contradictory results between earlier investigations of mycoplasmas in joints, the isolation techniques used will receive special attention.

\section{Materials and methods}

PATIENTS

The conditions diagnosed in the 129 patients studied are given in Table II. 57 had classical or definite rheumatoid arthritis according to the American Rheumatism Association criteria (Ropes, Bennett, Cobb, Jacox, and Jessar, 1958), 31 of whom were factor-positive. The patients with rheumatoid arthritis had had the disease for some months to several decades. At the time of sampling, 46 of the patients with RA were on treatment with chloroquine and sixteen also received prednisolone. Gold salts had been given to seven, but at the latest more than 6 months before sampling. In most of the patients steroids had been injected into that joint from which synovial fluid was collected and, in four, osmium tetraoxide, but never within the last 4 months before sampling. None of the nonrheumatoid patients had been treated with antibiotics or antirheumatic agents before sampling.

Table I Reports on the isolation of mycoplasmas from synovial fluid and/or membrane of patients with rheumatoid and nonrheumatoid arthritis

\begin{tabular}{|c|c|c|c|c|c|c|c|c|}
\hline \multirow[t]{2}{*}{ Author(s) } & \multirow[t]{2}{*}{ Date } & \multicolumn{2}{|c|}{$R A$ patients } & \multirow[t]{2}{*}{ Species found* } & \multicolumn{2}{|c|}{ NonRA patients } & \multirow{2}{*}{ Species found* } & \multirow{2}{*}{$\begin{array}{l}\text { Isolation } \\
\text { technique }\end{array}$} \\
\hline & & No. & Positive & & No. & Positive & & \\
\hline Jonsson & 1961 & 12 & 0 & & 25 & 12 & & $\mathbf{M}$ \\
\hline Igari and Arai & 1964 & 10 & 5 & & & & & $\mathbf{M}$ \\
\hline Bartholomew & 1965 & 6 & 5 & $\begin{array}{l}\text { M. hyorhinis } \\
\text { M. hominis }\end{array}$ & 12 & 4 & $\begin{array}{l}\text { M. arthritidis } \\
\text { M. hominis }\end{array}$ & $\mathbf{M}, \mathbf{T}$ \\
\hline $\begin{array}{l}\text { Fahlberg, Moore, Redmond, } \\
\text { and Brewer }\end{array}$ & 1966 & 24 & 22 & & 14 & 2 & & $\mathbf{M}$ \\
\hline Ford & 1967 & & & & 15 & $\mathbf{0}$ & & $\mathrm{M}, \mathrm{T}$ \\
\hline Williams & 1968 & 90 & 36 & M. fermentans & 37 & 8 & $M$. fermentans & $\mathrm{M}, \mathrm{S}$ \\
\hline $\begin{array}{l}\text { Dunlop, Hare, Jones, and } \\
\text { Taylor-Robinson }\end{array}$ & 1969 & 18 & 0 & & 16 & 3 & T-mycoplasmas & $\mathbf{M}$ \\
\hline Sharp & 1970 & 8 & 0 & & 8 & 0 & & $\mathbf{E}, \mathbf{M}$ \\
\hline $\begin{array}{l}\text { Jansson, Mäkisara, Vainio, } \\
\text { Snellman, and Tuuri }\end{array}$ & 1971 & 27 & 27 & M. arthritidis & 12 & $\mathbf{0}$ & & EM \\
\hline
\end{tabular}

* Species indicated in case of typing performed.

+ Specimens primary inoculated into: $\mathbf{E}=$ embryonated hen's egg; $\mathbf{E M}=$ egg yolk-containing mycoplasma medium; $\mathbf{M}=$ mycoplasma medium; $\mathbf{T}=$ tissue cell culture. 
Table II Isolation of mycoplasmas from synovial fluid from patients with various arthritic conditions

\begin{tabular}{|c|c|c|c|}
\hline \multirow[t]{2}{*}{ Diagnosis } & \multirow[t]{2}{*}{ No. of patients } & \multicolumn{2}{|c|}{ Synovial fluids yielding growth } \\
\hline & & M. fermentans & M. hominis \\
\hline $\begin{array}{l}\text { RA Factor-positive } \\
\text { Factor-negative }\end{array}$ & $\begin{array}{l}31 \\
26\end{array}$ & $\begin{array}{l}1 \\
2\end{array}$ & 1 \\
\hline Juvenile RA & 8 & & \\
\hline $\begin{array}{l}\text { Gout } \\
\text { Osteoarthrosis } \\
\text { Post-traumatic synovitis } \\
\text { Psoriatic arthritis } \\
\text { Pyrophosphate synovitis } \\
\text { Reiter's syndrome } \\
\text { Gonitis (unclassified) }\end{array}$ & $\begin{array}{r}1 \\
16 \\
13 \\
2 \\
13 \\
13 \\
3 \\
16\end{array}$ & $\begin{array}{l}1 \\
1\end{array}$ & \\
\hline Total & 129 & 5 & 1 \\
\hline
\end{tabular}

\section{SAMPLING TECHNIQUES}

Synovial fluid was aspirated from knee joints under aseptic conditions. Voided urine specimens were collected from the female RA patients without previous cleansing of the urethral orifice, while specimens from the males with RA were collected from the urethra with sterile cotton-tipped swabs. All specimens were cultured within 3 hours of sampling.

MEDI A

Mycoplasma media

The mycoplasma media used have been described in detail elsewhere (Mårdh and Weström, 1970a). Briefly, one medium consisted of brain-heart infusion broth (Difco) containing 20 per cent. horse serum, $2 \cdot 5$ per cent. yeast extract, $1: 2,000$ thallium acetate, and $1,500 \mathrm{u}$. penicillin $\mathrm{G}$ per $\mathrm{ml}$. Solid medium consisted of this liquid medium with the addition of $1 \cdot 13$ per cent. Oxoid Ionagar no. 2 . Liquid media consisting of PPLO broth (Difco) with addition of the above-mentioned ingredients as well as 10 per cent. glucose, or 1 per cent. arginine, and 0.002 per cent. phenol red were also used. The T-mycoplasma medium consisted of trypticase soya broth (BBL) to which horse serum, penicillin, and agar were added in the amounts given above. A liquid medium of the same composition, but containing also 0.1 per cent. urea and 0.002 per cent. phenol red, was used for demonstrating urease activity of T-mycoplasmas (Mårdh, Lohi, and Fritz, 1972).

\section{Media for bacteria}

Tryptone soya broth, thioglycollate broth, blood- and haematin-agar plates were used for isolating bacteria. The medium used for L-phase variants of bacteria was made of: brain-heart infusion agar (Difco) $45 \mathrm{ml}$., horse serum $20 \mathrm{ml}$., yeast extract (25 per cent.) $10 \mathrm{ml}$., $\mathrm{MgSO}_{4} .7 \mathrm{H}_{2} \mathrm{O}$ (20 per cent.) $0.85 \mathrm{ml}$., sucrose $8 \cdot 5 \mathrm{~g}$. and 2,3,5-triphenyltetrazoliumchloride (1 per cent.) $1 \mathrm{ml}$.

\section{ISOLATION TECHNIQUES}

\section{Isolation of mycoplasmas}

Of each synovial fluid, $0 \cdot 1 \mathrm{ml}$. was inoculated into $2 \mathrm{ml}$. of the liquid media. The brain-heart infusion broths were plated after 3 days' incubation. The PPLO broths containing glucose or arginine were observed for colour-changes
(Taylor-Robinson and Purcell, 1966) for 1 month before being discarded. The synovial fluids were also inoculated onto the solid medium, which was incubated in boxes insufflated with a gas mixture of 90 per cent. $\mathrm{N}_{2}$ and 10 per cent. $\mathrm{CO}_{2}$. In addition, the synovial fluids from forty of the patients with RA were cultured on agar plates, which $\omega$ were incubated in anaerobic jars in an atmosphere of 94 per cent. $\mathrm{H}_{2}$ and 6 per cent. $\mathrm{CO}_{2}$. The plates were repeatedly read under a stereomicroscope for 1 month. The solid Tmycoplasma medium was incubated for 3 weeks in the boxes described above. The medium used for demonstrating urease activity of T-mycoplasmas was observed for the same period of time. All cultures were made at $37^{\circ} \mathrm{C}$.

The synovial fluids from 54 of the patients with RA were centrifuged on sucrose density gradients, as suggested by Williams (1968). These fluids had been stored at $-80^{\circ} \mathrm{C}$. for from 1 week to 6 months. Gradients ranging from 50 to 90 per cent. sucrose were prepared and allowed to equilibrate over night. Of the specimens, $0.5 \mathrm{ml}$. was poured over the gradients, which hold $3 \mathrm{ml}$. Centrifugation was done at $33.000 \times \mathrm{G}$. at $4{ }^{\circ} \mathrm{C}$. for 2 hours in an MSE Superspeed 65 Ultracentrifuge. Fractions of $0.3 \mathrm{ml}$. were collected and inoculated into the glucose-containing PPLO broth, which was incubated for 4 days and then plated. Before being discarded the broth cultures were observed for 1 month for colour-changes.

The methods used for identifying mycoplasmas and for isolating them from the urogenital tract have been described elsewhere (Mårdh and Weström, 1970a).

\section{Isolation of bacteria and L-phase variants}

The synovial fluids were cultured for bacteria on blood agar plates, which were incubated aerobically and also in ? anaerobic jars, as described above, and on haematin agar plates incubated in 10 per cent. $\mathrm{CO}_{2}$. The plates as well as the cultures in thioglycollate broth were kept for 1 week. The tryptone soya broths were incubated at $4^{\circ} \mathrm{C}$. and observed for 6 months (for recovery of Listeria monocytogenes). The medium for L-phase variants was incubated and read in the way described for the solid mycoplasma medium. 
ANTIMICROBIAL SUSCEPTIBILITY TESTS

These were made with the agar plate dilution technique as described elsewhere (Weström and Mårdh, 1971). The antibiotics used (Table VI) were from the same sources as in that investigation. Sodium aurothiosulphate (Sanocrysin ${ }^{\circledR}$ ) was obtained from Ferrosan, Copenhagen, and chloroquine phosphate from ACO, Stockholm.

\section{SEROLOGICAL TECHNIQUES}

Sera of the patients with RA were tested for indirect haemagglutinating (IHA) and metabolism-inhibiting (MI) antibodies to $M$. fermentans. In addition, sera from 84 age- and sex-matched controls were examined for IHA antibodies to $M$. fermentans and 71 of them also for MI antibodies to this organism. The IHA antibody tests were performed with a technique described earlier (Mårdh and Weström, 1970b). Rabbit immune sera to $M$. fermentans, used in the tests as a control, had an IHA antibody titre of $1: 2,048$. The MI antibody tests were made essential in the way described by Taylor-Robinson, Purcell, Wong, and Chanock (1966). One volume of serum heated at $56^{\circ} \mathrm{C}$. for 30 minutes was titrated in an equal volume of a broth culture of $M$. fermentans, which consisted of a freshly prepared mixture of 36-hour broth cultures of four strains isolated from synovial fluid. Finally, five volumes of fresh PPLO broth containing glucose $(\mathrm{pH} 7.8)$ were added to each cup. The tests were read when a colour-change corresponding to a decrease of the $\mathrm{pH}$ by 0.8 unit had occurred in the cups containing mycoplasmas but no sera. The rabbit immune sera had an MI antibody titre of $1: 128$.

\section{Results}

\section{Isolation of mycoplasmas from synovial fluid}

$M$. fermentans was isolated from synovial fluid from three of the 57 patients with RA, from none of the eight juvenile RA patients, and from two of the 64 patients with nonrheumatoid arthritis. The recovery rate in the group of the rheumatoid and the nonrheumatoid arthritis patients did not differ from one another $(P>0 \cdot 5)$. M. hominis was isolated from one of the other patients with RA. The anaerobic cultures gave growth of mycoplasmas only in those cases in which the cultures incubated in $\mathrm{N}_{2}$ and $\mathrm{CO}_{2}$ were also positive. Neither were any additional strains of Mycoplasma recovered in the broths containing glucose or arginine. After centrifugation on the sucrose density gradients, mycoplasmas could not be isolated from any of the specimens. T-mycoplasmas were not found in any of the joint effusions and urease activity was never demonstrable.

\section{Isolation of bacteria from synovial fluid}

On the conventional media for bacteria, culture of the synovial fluid of one of the patients with nonrheumatoid arthritis gave sparse growth of coagulasepositive staphyloccocci and that of another, coliform rods, while no growth of bacteria was obtained from the synovial fluids from the patients with RA. On the medium for L-phase variants, sparse growth of Corynebacterium hofmanii was obtained from synovial samples from three of the patients with RA and eleven of those with nonrheumatoid arthritis. The diphtheroid rods appeared in their bacterial form on this medium. When subcultured on blood agar plates, they gave heavy growth. Diphtheroid rods were not found on the blood agar plates that had been inoculated directly with synovial fluid.

\section{Isolation of mycoplasmas from the urinary tract of the patients with $R A$}

$M$. fermentans was isolated from the urethra of one of the male patients with RA (Table III) and from a urine specimen of one of the patients with nonrheumatoid arthritis. In the latter case, $M$. fermentans was also found in synovial fluid. $M$. hominis was cultured from the urethra or from urine specimens of 10.6 per cent. of the 57 patients with RA studied, including the one from whom this organism was recovered from joint effusion. T-mycoplasmas were found in 19.4 per cent. of the patients. No mycoplasmas were found in the urogenital tract of the children with juvenile RA.

\section{Serological studies of Mycoplasma fermentans}

Few ( 6.2 per cent.) of the patients with adult or juvenile RA as well as of the controls (6.0 per cent.) had IHA antibodies to $M$. fermentans at a titre of at least $1: 16$ (Table IV). There was no difference between the prevalence of such antibodies in the group of patients with RA and nonRA $\left(\chi^{2}=1 \cdot 2821 ; \mathrm{P}>0 \cdot 5\right)$. Only one of the patients from whom this organism had been recovered from synovial fluid had such antibodies.

MI antibodies to $M$. fermentans at a titre of at least $1: 16$ were found in $9 \cdot 2$ per cent. of the patients with

Table III Isolation of mycoplasmas from the urogenital tract of patients with rheumatoid arthritis*

\begin{tabular}{|c|c|c|c|c|c|}
\hline & \multirow[t]{2}{*}{ No. of patients } & \multirow[t]{2}{*}{$\operatorname{Sex}$} & \multicolumn{3}{|c|}{ Specimens yielding growth } \\
\hline & & & M. fermentans & M. hominis & $T$-mycoplasmas \\
\hline & $\begin{array}{l}45 \\
20\end{array}$ & $\begin{array}{l}\mathbf{F} \\
\mathbf{M}\end{array}$ & $\begin{array}{l}0 \\
1\end{array}$ & $\begin{array}{l}4 \\
2\end{array}$ & $\begin{array}{l}8 \\
3\end{array}$ \\
\hline Total & 65 & & 1 & 6 & 11 \\
\hline
\end{tabular}

* From the female patients cultures were made from voided urine specimens and from the males from urethral swabs. 
Table IV Indirect haemagglutinating (IHA) antibodies to Mycoplasma fermentans in sera from patients with rheumatoid arthritis and from controls

\begin{tabular}{|c|c|c|c|c|c|}
\hline \multirow[t]{2}{*}{ Group } & \multirow[t]{2}{*}{ No. of subjects } & \multicolumn{4}{|c|}{ Subjects with IHA antibodies to $\mathrm{M}$. fermentans (titre) } \\
\hline & & $1 /<16$ & $1 / 16$ & $1 / 32$ & $1 / 64$ \\
\hline \multirow{2}{*}{$\begin{array}{l}\text { RA } \\
\text { Juvenile RA } \\
\text { Controls }\end{array}$} & \multirow{2}{*}{$\begin{array}{r}57 \\
8 \\
84\end{array}$} & \multirow{2}{*}{$\begin{array}{r}53 \\
8 \\
79\end{array}$} & 2 & 1 & 1 \\
\hline & & & 3 & 1 & 1 \\
\hline Total & 149 & 140 & 5 & 2 & 2 \\
\hline
\end{tabular}

Table V Metabolism-inhibiting (MI) antibodies to Mycoplasma fermentans in sera from patients with rheumatoid arthritis and from controls

\begin{tabular}{|c|c|c|c|c|c|}
\hline \multirow[t]{2}{*}{ Group } & \multirow[t]{2}{*}{ No. of subjects } & \multicolumn{4}{|c|}{ Subjects with MI antibodies to $\mathrm{M}$. fermentans (titre) } \\
\hline & & $1 /<16$ & $1 / 16$ & $1 / 32$ & $1 / 64$ \\
\hline $\begin{array}{l}\text { RA } \\
\text { Juvenile RA } \\
\text { Controls }\end{array}$ & $\begin{array}{r}57 \\
8 \\
71\end{array}$ & $\begin{array}{r}52 \\
7 \\
68\end{array}$ & 4 & $\begin{array}{l}1 \\
1\end{array}$ & 1 \\
\hline Total & 136 & 127 & 6 & 2 & 1 \\
\hline
\end{tabular}

adult or juvenile RA and in $4 \cdot 2$ per cent. of the controls (Table V); the difference was not significant $\left(\chi^{2}=0.6850 ; P>0.5\right)$. M. fermentans had been recovered from synovial fluid of two of the seven patients with such antibodies.

Susceptibility of Mycoplasma fermentans to antibiotics, gold, and chloroquine

The five strains of $M$. fermentans isolated from synovial fluid had roughly the same susceptibility pattern (Table VI). They were most susceptible to lincomycin and tetracyclines, less to erythromycin, and least to chloramphenicol, aurothiosulphate, and chloroquine sulphate.

\section{Case reports}

Case 1, a 58-year-old woman, had had classical rheumatoid arthritis since 1968; the disease had progressed rapidly despite treatment with corticosteroids and intermittently with chloroquine. Gold treatment was discontinued in the summer of 1970 because of side-effects. In the autumn of 1970 the disease became more active and culminated in December, when the patient was treated with cytostatics for 3 weeks. Synovectomy of the right knee joint was done in the spring of 1971. After the operation, the patient was treated with tetracycline for 3 months. During this period the symptoms rapidly subsided. No exacerbations have since occurred.

A heavy growth of $M$. fermentans was obtained from synovial fluid collected from the right knee joint in October and December, 1970, while a specimen from the same joint 4 months later gave no growth. In sera collected on these three occasions, MI antibodies to $M$. fermentans were demonstrated at titres of $1: 16,1: 32$, and $1: 16$, but no IHA antibodies.

Case 2, a woman aged 62, had had definite rheumatoid arthritis since 1959. Gradual involvement of most joints

Table VI Susceptibility of Mycoplasma fermentans isolated from synovial fluid to some antibiotics, gold and chloroquine

\begin{tabular}{|c|c|c|c|c|c|c|c|c|c|c|}
\hline \multirow{3}{*}{ Substance } & \multicolumn{10}{|c|}{$M I C(\mu \mathrm{g} . / \mathrm{ml})}$. \\
\hline & \multicolumn{10}{|c|}{ Cumulative number of strains inhibited by: } \\
\hline & 0.05 & $0 \cdot 1$ & $0 \cdot 2$ & 0.4 & 0.8 & 1.6 & $3 \cdot 2$ & $6 \cdot 4$ & $12 \cdot 8$ & $25 \cdot 6$ \\
\hline Tetracycline & & & & 5 & & & & & & \\
\hline Oxytetracycline & & & & 3 & 5 & & & & & \\
\hline Metacycline & & & & 5 & & & & & & \\
\hline $\begin{array}{l}\text { Doxycycline } \\
\text { Lincomycin }\end{array}$ & & & & 4 & 5 & & & & & \\
\hline $\begin{array}{l}\text { Lincomycin } \\
\text { Erythromycin }\end{array}$ & & 5 & & & & & 1 & 5 & & \\
\hline Chloramphenicol & & & & & & & & & 1 & 5 \\
\hline $\begin{array}{l}\text { Sodium aurothiosulphate } \\
\text { Chloroquine phosphate }\end{array}$ & & & & & & & & & & 5 \\
\hline Chloroquine phosphate & & & & & & & & & 1 & 5 \\
\hline
\end{tabular}


led to increasing invalidity. In 1971 , during a moderate exacerbation of the disease, synovial fluid from one of the knee joints gave scanty growth of $M$. fermentans. No IHA or MI antibodies to this organism were demonstrable in serum.

Case 3, a 43-year-old man, had definite rheumatoid arthritis. Since the onset in 1944 the disease had gradually progressed with involvement of most joints. In 1970 he had an exacerbation and chloroquine treatment was initiated. During this period, synovial fluid was obtained on two occasions within 1 month. The first specimen gave a sparse growth of $M$. fermentans and the second, none. On the first occasion, IHA antibodies to $M$. fermentans were demonstrated at a titre of $1: 16$, but no MI antibodies.

Case 4, a woman aged 38, had had diffusely localized pain in the lower lumbar region, radiating to both hips and thighs since 1968, and acute pain and swelling of the right knee joint in 1970. She had since had migratory arthralgias most often confined to the large joints. RAfactor test was negative. No arthritic changes were seen on $x$-ray films.

In 1970, synovial fluid specimens from the right knee joint gave a sparse growth of $M$. fermentans, but 6 months later culture of synovial fluid from the same knee joint gave no growth. Sera, which were obtained only on this last occasion, contained no IHA or MI antibodies.

Case 5, a 79-year-old woman, had had recurrent attacks of synovitis in the knee joints since 1965 . In 1970, polarized light microscopy of joint fluid revealed pyrophosphate crystals. Since that year the patient also experienced pain and morning stiffness symmetrically in the peripheral joints. RA-factor test was negative. $x$-ray films of the left knee joint showed cartilage calcifications and advanced osteoarthrosis, but no roentgenologic signs of arthritis.

In 1970 a culture of synovial fluid from the left knee joint gave a heavy growth of $M$. fermentans. Cultures of specimens obtained from the same joint 1 and 4 months later showed no growth. $M$. fermentans was also found in a urine specimen collected 3 weeks after the first sampling of synovial fluid. On that occasion the serum contained MI antibodies to $M$. fermentans at a titre of $1: 16$. Serum obtained at the same time as the last two samples of synovial fluid contained such antibodies at a titre of $1: 128$ and $1:<16$, respectively. IHA antibodies were not detected in any of the serum specimens.

Case 6, a 60-year-old man, had factor-negative RA with subacute onset in 1967; primary involvement of the knee joints was followed by gradual engagement of most joints. Because of the pronounced activity of the disease, steroid treatment was started in 1969 and chloroquine in 1970 . He underwent synovectomy of the left knee joint in 1970. The symptoms subsided until 1972, when an exacerbation involved both knee joints. Intraarticular steroids and treatment with tetracycline for 2 months had no demonstrable effect.

Just before the synovectomy in 1970, synovial fluid from the left knee joint gave a growth of $M$. hominis. A specimen collected from the other knee joint 4 months later yielded no growth. Synovial fluid collected from the left knee joint during the exacerbation in 1972 again gave growth of
M. hominis. Repeated cultures of specimens from both knee joints after treatment with tetracycline in 1972 were all negative. Three serum specimens obtained during the exacerbation that year contained IHA antibodies to $M$. hominis at titres of $1: 128,1: 128$, and $1: 64$. The titres of MI antibodies to this organism in these three specimens were $1: 32,1: 32$, and $1: 16$, respectively. No antibodies to M. hominis were found in sera obtained in 1970.

\section{Discussion}

Mycoplasmas cause various arthritides in animals (c.f. Decker, 1966; Sharp, 1971). This has encouraged attempts to demonstrate mycoplasmas also in arthritic conditions in man, but the overall picture of the results of these studies is confusing; the reported recovery rates of mycoplasmas in series of synovial fluid or tissue have varied from zero to 100 per cent., and animal mycoplasma species have been reported in human joint specimens (Table I). It seems plausible that differences in isolation techniques may partly account for the contradictory results obtained. Since mycoplasmas frequently occur as contaminants of tissue cell cultures, the use of such cultures for demonstrating mycoplasmas in clinical specimens leads to doubts about the origin of the organisms. Repeated passages and prolonged cultivation can also increase the risk of contamination of the cultures. This risk can be reduced, though not excluded, by inoculation directly onto solid mycoplasma medium, as used in the present study.

Diphtheroid rods and their L-phase variants have been isolated from synovial fluid and membrane (Duthie and others, 1967; Bartholomew and Nelson, 1972a). In contrast with the findings in earlier studies, we found diphtheroid rods more often in synovial fluid of patients with nonrheumatoid arthritis than in those with RA. Although the organisms were recovered on a medium for L-phase variants, nothing suggested that they grew as variants on this medium. Since diphtheroid rods normally occur on the skin, contamination of the synovial fluids during sampling could not be excluded. However, phenol extracts of synovial fluid leucocytes have been reported to give precipitation lines identical with Corynebacterium acnes, when tested against antisera to this organism (Bartholomew and Nelson, 1972b).

The treatment given before sampling might influence the recovery rate of mycoplasmas from synovial fluid. Since little or no information on treatment has been given, it is not possible to say whether differences in this respect can explain the wide range of variation of the isolation rates reported. The MICs of gold salt and of chloroquine phosphate (Table VI) suggest that, with the doses given, the concentrations of these drugs reached in the joints (Schuster, Eberl, and Altmann, 1970) were probably not sufficient to eradicate mycoplasmas. 
The prevalence of $M$. fermentans in the urogenital tract of the patients with RA in the present series did not differ from that of an earlier series of 883 nonarthritic subjects in which this organism was found in 0.7 per cent. Neither did the prevalence of $M$. hominis or T-mycoplasmas differ from that in healthy controls (Mårdh, 1972). The urogenital tract may be considered as a possible portal of entry for joint infections with mycoplasmas. From one of our patients $M$. fermentans, and from another $M$. hominis, was isolated both from synovial fluid and urine.

There was no significant difference in the incidence of IHA or MI antibodies to M. fermentans between the patients with RA and the controls. Nor did Williams (1967) find that tests for such antibodies to $M$. fermentans could clearly distinguish patients with RA from controls. It is noteworthy that an antibody response to $M$. fermentans could be demonstrated in only two of the five patients from whom this organism was isolated from synovial fluid.

Williams and others (1970) reported that $M$. fermentans, but not other mycoplasma species studied, took up IgG from the culture medium and firmly bound it to its membrane. Fragments of membranes of this organism grown in human serum were agglutinated by human rheumatoid factor. In a preliminary study (Kronvall and Mårdh, unpublished observations), ${ }^{125}$ I labelled human IgG and membranes of sonicated $M$. fermentans organisms (of a strain isolated from synovial fluid), which had been subcultured in an IgG-free mycoplasma medium, were used. Urea-treated membranes of organisms grown in PPLO broth containing horse serum were also tested. But no adsorption of IgG to the membranes could be demonstrated.

Different factors which might influence the possibility of isolating $M$. fermentans from synovial fluid were considered. Freundt (1958) reported that an anaerobic atmosphere stimulates growth of this organism, but we did not find that the use of such cultures improved the recovery rate of $M$. fermentans from synovial fluid. After incubation, extracts of various tissues, including synovial membrane, kill mycoplasmas (Kaklamanis, Stavropoulos, and Thomas, 1971). Various methods for overcoming the mycoplasmacidal effect of tissue extracts have recently been described (Mårdh and Taylor-Robinson, 1973). Since Taylor-Robinson (1972) found an inhibitory effect of synovial fluid from certain individuals on the growth of mycoplasmas, these methods were applied for the isolation of mycoplasmas from such specimens. However, these methods revealed no mycoplasmas in joint effusion of ten patients with RA. Edward (1971) found M. fermentans to be more sensitive to the cholesterol content of the culture medium than other mycoplasma species studied. This sensitivity might interfere with the recovery of $M$. fermentans from synovial fluid with conventional mycoplasma media. Williams (1968), who used sucrose density gradients for the isolation of mycoplasmas from joint effusion, reported a frequent occurrence of $M$. fermentans. We obtained no growth of mycoplasmas from such specimens, stored at $-80^{\circ} \mathrm{C}$., when using this method. The centrifugation of broth cultures of $M$. fermentans resulted in a considerable loss of the number of colony-forming units put on the gradients.

The possibility of screening synovial fluid for mycoplasmas by inoculating them into mycoplasma media visualizing the ability of these organisms to metabolize glucose and/or arginine, or urea (c.f. Taylor-Robinson and Purcell, 1966) was studied. The results of these cultures agreed with those obtained on solid media, which indicate the value of such media for screening. The glucose concentration in synovial fluid of the patients with RA was also studied for its possible value as a screening test for glucose-fermenting mycoplasmas, such as $M$. fermentans. The glucose concentrations were found to vary widely and no correlation could be demonstrated between these concentrations and the results of the cultures for M. fermentans.

This study suggests that mycoplasmas may occur and may also persist in arthritic joints, but the clinical significance of such infections is at present difficult to assess. It was not possible to attribute the finding of mycoplasmas in synovial fluid to any characteristic clinical picture or to correlate it with the result of any of the laboratory tests made in the present cases.

\section{Summary}

Synovial fluids from 57 patients with RA, eight with juvenile RA, and 64 with nonrheumatoid arthritis were cultured for mycoplasmas, bacteria, and Lphase variants of bacteria. Mycoplasma fermentans was isolated from joint effusions from three of the patients with RA and from two of the patients with nonrheumatoid arthritis, and $M$. hominis from a further effusion from a patient with RA. In all instances growth was obtained by direct inoculation into mycoplasma media. Prolonged incubation of the cultures, anaerobic cultures, and centrifugation of the specimens in sucrose density gradients before culture did not increase the recovery rate. Mycoplasmas were not found more often in the urogenital tract of the RA patients than in that of healthy controls. IHA and MI antibodies to $M$. fermentans were detectable in only a few of the RA patients and there was no significant difference in the prevalence of such antibodies between the patients with RA and the healthy controls. Corynebacterium hofmanii was isolated on a medium for L-phase variants from the synovial fluid of three of the patients with RA and eleven of those with nonrheumatoid arthritis. 


\section{References}

BARTHOLomew, L. E. (1965) Arthr. and Rheum., 8, 376 (Isolation and characterization of mycoplasmas (PPLO) from patients with rheumatoid arthritis, systemic lupus erythematosus and Reiter's syndrome)

- ANd Nelson, F. R. (1972a) Ann. rheum. Dis., 31, 22 (Corynebacterium acnes in rheumatoid arthritis. I. Isolation and antibody studies)

-, 1 (1972b) Ibid., 31, 28 (Corynebacterium acnes in rheumatoid arthritis. II. Identification of antigen in synovial fluid leucocytes)

DECKeR, J. L. (ed.) (1966) 'The Relationship of Mycoplasma to Rheumatoid Arthritis and Related Diseases', Public Health Service Publication, No. 1523. National Institutes of Health, Bethesda, Maryland

Dunlop, E. M. C., Hare, M. J., Jones, B. R., and Taylor-Robinson, D. (1969) Brit. J. vener. Dis., 45, 274 (Mycoplasmas and 'non-specific' genital infection. II. Clinical aspects)

Duthie, J. J. R., Stewart, S. M., AleXANDer, W. R. M., AND DayHOFF, R. E. (1967) Lancet, 1, 142 (Isolation of diphtheroid organisms from rheumatoid synovial membrane and fluid)

EDWARD, D. G. ff. (1971) J. gen. Microbiol., 69, 205 (Determination of sterol requirement for Mycoplasmatales)

FAhlberg, W. J., MoOre, R. W., Redmond, H. E., ANd BReWer, E. J., JR. (1966) Bact. Proc., 66, 48 (Isolation of Mycoplasma from human synovial fluids and tissues)

Ford, D. K. (1967) Ann. N.Y. Acad. Sci., 143, 501 (Relationships between Mycoplasma and the etiology of nongonococcal urethritis and Reiter's syndrome)

Freundt, E. A. (1958) 'The Mycoplasmataceae', p. 54. Munksgaard, Copenhagen

IgARI, T., ANd ARAI, M. (1964) J. Iwate med. Ass., 16, 15 (Pleuropneumonia-like organisms (PPLO) in synovial fluids: Considerations on the etiology of rheumatoid arthritis)

Jansson, E., Mäkisara, P., Vainio, K., Snellman, O., AND TuURi, S. (1971) Acta rheum. scand., 17, 227 (Further studies on Mycoplasma in rheumatoid arthritis)

Jonsson, J. (1961) Ibid., 7, 287 (Mycoplasma organisms in synovial fluid from rheumatic joints)

Kaklamanis, E., Stavropoulos, K., AND Thomas, L. (1971) In' Mycoplasma and the L forms of Bacteria', ed. S. Madoff, p. 27. Gordon and Breach, New York and London

Kronvall, G., AND MÅrdH, P.-A.: Unpublished data.

MÅRDH, P.-A. (1972) 'Mycoplasmas in Acute Salpingitis and in Colpitis and their Occurrence in Urine'. Staffanstorps Tryckeri AB, Lund.

- LOHI, A., AND FRITZ, H. (1972) Acta med. scand., 191, 91 (Mycoplasma in urine collected by suprapubic aspiration) AND TAYLOR-Robinson, D. (1973) Med. Microbiol. Immunol., 158 (New approaches to the isolation of mycoplasmas)

— AND WESTRÖM, L. (1970a) Brit. J. vener. Dis., 46, 179 (Tubal and cervical cultures in acute salpingitis with special reference to Mycoplasma hominis and T-strain mycoplasmas) controls)

Ropes, M. W., Bennett, G. A., Cobb, S., Jacox, R. F., And Jessar, R. A. (1959) Ann. rheum. Dis., 18, 49 (Revision of diagnostic criteria for rheumatoid arthritis)

SChuster, F., Eberl, R., AND AltMAnN, H. (1970) Z. Rheumaforsch., 29, 193 (Über Goldbestimmungen in synovialem Gewebe und Nebenwirkungen der Goldtherapie)

Sharp, J. T. (1970) Arthr. and Rheum., 13, 263 (Mycoplasmas and arthritis)

(1971) Ibid., 14, 286 (Mycoplasmas)

Smith, C. B., AND WARD, J. R. (1971) J. infect. Dis., 123, 313 ('Chronic infectious arthritis'-Role of mycoplasmas)

TAYLOR-ROBINSON, D. (1972) Personal communications

- ANd Purcell, R. H. (1966) Proc. roy. Soc. Med., 59, 1112 (Mycoplasmas of the human urogenital tract and oropharynx and their possible role in disease; a review with some recent observations)

- WONG, D. C., AND CHANOCK, R. M. (1966) J. Hyg. (Camb.), 64, 91 (A colour test for the measurement of antibody to certain mycoplasma species based upon the inhibition of acid production)

WeSTRÖM, L., AND MÅRDH, P.-A. (1971) Acta obstet. gynec. scand., 50, 25 (The effect of antibiotic therapy on Mycoplasma in the female genital tract)

Williams, M. H. (1967) Ph.D. Thesis, Welsh National School of Medicine (Mycoplasmas in human disease) (1968) 'Recovery of Mycoplasma from rheumatoid synovial fluid' in 'R heumatic Diseases', ed. J. J. R. Duthie and W. R. M. Alexander, p. 172. Pfizer Medical Monographs No. 3, University Press, Edinburgh.

-, Brostoff, J., AND RoITt, I. M. (1970) Lancet, 2, 277 (Possible role of Mycoplasma fermentans in pathogenesis of rheumatoid arthritis) 